\title{
Cooperative management and its effects on shade tree diversity, soil properties and ecosystem services of coffee plantations in western El Salvador
}

\author{
V. Ernesto Méndez • Elizabeth N. Shapiro • \\ Gregory S. Gilbert
}

Received: 31 July 2008/Accepted: 23 February 2009/Published online: 10 March 2009

(C) The Author(s) 2009. This article is published with open access at Springerlink.com

\begin{abstract}
We compared how management approaches affected shade tree diversity, soil properties, and provisioning and carbon sequestration ecosystem services in three shade coffee cooperatives. Collectively managed cooperatives utilized less diverse shade, and pruned coffee and shade trees more intensively, than individual farms. Soil properties showed significant differences among the cooperatives, with the following properties contributing to differentiation: $\mathrm{N}, \mathrm{pH}, \mathrm{P}, \mathrm{K}$, and $\mathrm{Ca}$. Higher tree richness was associated with higher soil $\mathrm{pH}$, $\mathrm{CEC}, \mathrm{Ca}$, and $\mathrm{Mg}$, and lower $\mathrm{K}$. Higher tree densities were associated with lower N, K, and organic matter. Although we found differences in the incidence of provisioning services (e.g., fruit), all plantations generated products other than coffee. No differences were observed between $\mathrm{C}$-stocks. The history and institutional
\end{abstract}

V. E. Méndez $(\bowtie)$

Environmental Program/Department of Plant \& Soil Science, University of Vermont, The Bittersweet, 153 South Prospect St., Burlington, VT 05401, USA e-mail: Ernesto.Mendez@uvm.edu; emendez@uvm.edu

E. N. Shapiro

Department of Environmental Science,

Policy and Management, University of California, 137 Mulford Hall \#3114, Berkeley, CA 94720, USA e-mail: eshapiro@nature.berkeley.edu

G. S. Gilbert

Department of Environmental Studies, University of California, 1156 High St., Santa Cruz, CA 95064, USA

e-mail: ggilbert@ucsc.edu arrangements of cooperatives can influence management approaches, which affect ecosystem properties and services. Our study corroborates that interdisciplinary investigations are essential to understand the socioecological context of tropical shade coffee landscapes.

Keywords Agroecology · Agroforestry ·

Coffea arabica . Tree diversity .

Farmer organizations

\section{Introduction}

There is an increasing interest in exploring the potential for conserving and managing ecosystem services in agricultural landscapes (Swinton et al. 2007). Ecosystem services can be defined as the goods and services that humans derive from ecosystems and their functions (Costanza et al. 1997). These services can be further classified as provisioning services (e.g., food and fodder), regulating services (e.g., climate, water, and soil regulation), cultural services (e.g., education and recreation), and supporting services (e.g., primary production and nutrient cycling) (MA 2003). Ecosystem services associated with shade coffee production have generated much scientific and social interest over the last decades (Nestel 1995; Perfecto et al. 1996; Philpott and Dietsch 2003; Dietsch et al. 2004). Documented services include biodiversity conservation (Somarriba 
et al. 2004), carbon (C) sequestration (Segura et al. 2006), and soil and water conservation (Babbar and Zak 1995; Ataroff and Monasterio 1997). The primary focus of scientific research has been to analyze how shade tree composition affects the species richness and abundance of the native plants and animals that use shade coffee as an extension of their natural forest habitat (Greenberg et al. 1997; Moguel and Toledo 1999; Perfecto and Vandermeer 2002; Perfecto et al. 2003; Somarriba et al. 2004). Complementary research has focused mainly on improving agroforestry management practices to increase the compatibility of shade coffee production with shade trees that provide provisioning services (e.g., timber, fruit, and firewood) and supporting ecosystem services (e.g., shade, N-fixation, and organic matter contribution; Beer 1987; Somarriba 1990; Beer et al. 1998; Peeters et al. 2003). Recent work has also highlighted the desirability to explicitly combine $\mathrm{C}$ sequestration with biodiversity conservation in agroforestry systems (Kirby and Potvin 2007). Research that integrates an analysis of the provision of ecosystem services with the institutional oversight and management practices of agroecosystems is essential to the development of sustainable, multifunctional landscapes (Carpenter et al. 2006; Swinton et al. 2007).

An estimated 327,000 small-scale farmers cultivate about 809,000 ha of coffee in Central America and Mexico (Escamilla and Díaz 2002; Flores et al. 2002). Many of these small-scale growers are organized into farmer cooperatives, which can differ dramatically in terms of their history and function (Seligson 1995; Bacon 2005; Wollni and Zeller 2007; Westphal 2008). These farmers tend to maintain more diverse shade tree canopies, and dominate the certified organic and Fair Trade coffee markets (Rice and McLean 1999; Murray et al. 2003; Bacon et al. 2008). As public support for ecosystem service conservation in agroforestry-dominated landscapes increases (Schroth et al. 2004), researchers are focusing on developing a better understanding of the relationships between shade tree diversity and coffee plantation management, and its effects on specific agroecosystem properties (SotoPinto et al. 2000; Schroth et al. 2004; Bacon et al. 2008). However, an integral component of these systems - the relationship between farmer cooperative type and the management regimes they practice- - has received limited research attention. Shade tree and coffee plantation management in farmer cooperatives is affected by both cooperative-level management approaches (especially in collectively managed landholdings), and the livelihood needs of individual households (Bacon 2005; Méndez 2008; Westphal 2008). Research in Mexico and South America has found that the type, history and links to other organizations and social networks of farmer cooperatives are important factors that affect the way these organizations work, and the management practices that they promote (Fox 1992; Bebbington 1996, 1997; Trujillo 2008).

Management approaches related to shade tree density and diversity, pruning of trees and coffee bushes, and weeding have been shown to affect soil chemical and physical characteristics. A number of studies have demonstrated the impacts of shade and/ or coffee plant densities on nitrogen cycling and leaching (Babbar and Zak 1994, 1995; Verchot et al. 2006) and on erosion rates (Ataroff and Monasterio 1997). Others have focused on the relationships between types or diversity of shade tree species and nutrient and organic matter content of soils (Mogollón et al. 1997; Romero-Alvarado et al. 2002; Siebert 2002). Yet other studies have examined the relationship in shade coffee between specific management practices and soil characteristics, such as organic matter content, soil aggregation and nutrient content from shade tree residues (Beer 1988; Mendoca and Stott 2003; Hoyos and Comerford 2005; Payan et al. 2007; Teklay 2007), weed and mulch management (Afrifa et al. 2003; Sarno et al. 2004; Watanabe et al. 2007). Although we know from other systems that plant species composition can have significant impacts on availability and recycling of key nutrients in agroecosystems (Leblanc et al. 2007; Redel et al. 2007), and greater plant species diversity can increase nutrient use efficiency and reduce nutrient leaching (Tilman et al. 1996; Schroth et al. 2001), there has been little work on interactions between the agroecosystem properties of shade coffee systems and their collective impact on soil characteristics. A notable exception analyzed the effects of plant functional types (PFTs) and species assemblages on soil properties and other factors of coffee agroecosystems in Indonesia (Gillison et al. 2004).

Our study examined how differences in history and land tenure influenced the management choices of three coffee farmer cooperatives and how the differences in the resulting stewardship regime affected 
shade tree diversity and density, soil properties and ecosystem services. We do this by focusing on two research objectives. First, we analyzed how cooperative types and history affect approaches to managing shade trees, fertilization, coffee pruning and weed control and the effects of these on soil characteristics and shade tree density and diversity. Secondly, we asked whether increasing the species richness of shade trees (number of species), independently from increased the density of shade trees (number of trees), would change soil characteristics in ways that could affect ecosystem services. To do this we examined how cooperatives differed in coffee, fruit and firewood production (provisioning services) and carbon sequestration by shade trees (as a regulating service; MA 2003). Analysis of the residual species richness after removing the diversity-density relationship provided a mechanism for evaluating differences in diversity management across the cooperatives.

\section{Study site}

The study was conducted in three shade coffee farmer cooperatives in the municipality of Tacuba in western El Salvador $\left(13^{\circ} 50^{\prime}, 89^{\circ} 50^{\prime}\right.$, with average elevations of 897 masl; Fig. 1). Cooperatives 1 and 2 are collectively managed farms, of 195 and 35 ha, respectively. In contrast, Cooperative 3 consisted of 28 independently owned farms dispersed over a heterogeneous landscape. Average farm size in Cooperative 3 was 0.94 ha, including residential areas, subsistence crop areas, and shade coffee fields.

The climate is subtropical humid with the rainy season lasting approximately from May through October. The natural vegetation in the area is Holdridge life zone 4, or humid, subtropical forest, and soils are predominantly Andisols of volcanic origin (MARN 2003). The cooperatives are located in or near the buffer zone to El Impossible National Park (PNEI, for its Spanish name), one of the largest protected natural forests in the country. Plantations were cultivated with Coffea arabica L. only, and almost exclusively with the 'Pacas' and 'Bourbon' varieties.

\section{Materials and methods}

Cooperative institutional analysis, management histories and tree use

Information on cooperative history, institutional arrangement and tree use was compiled through household surveys $(n=52)$, focus groups and semi-
Fig. 1 Location of the three coffee cooperatives and sampling plots in Tacuba, western El Salvador

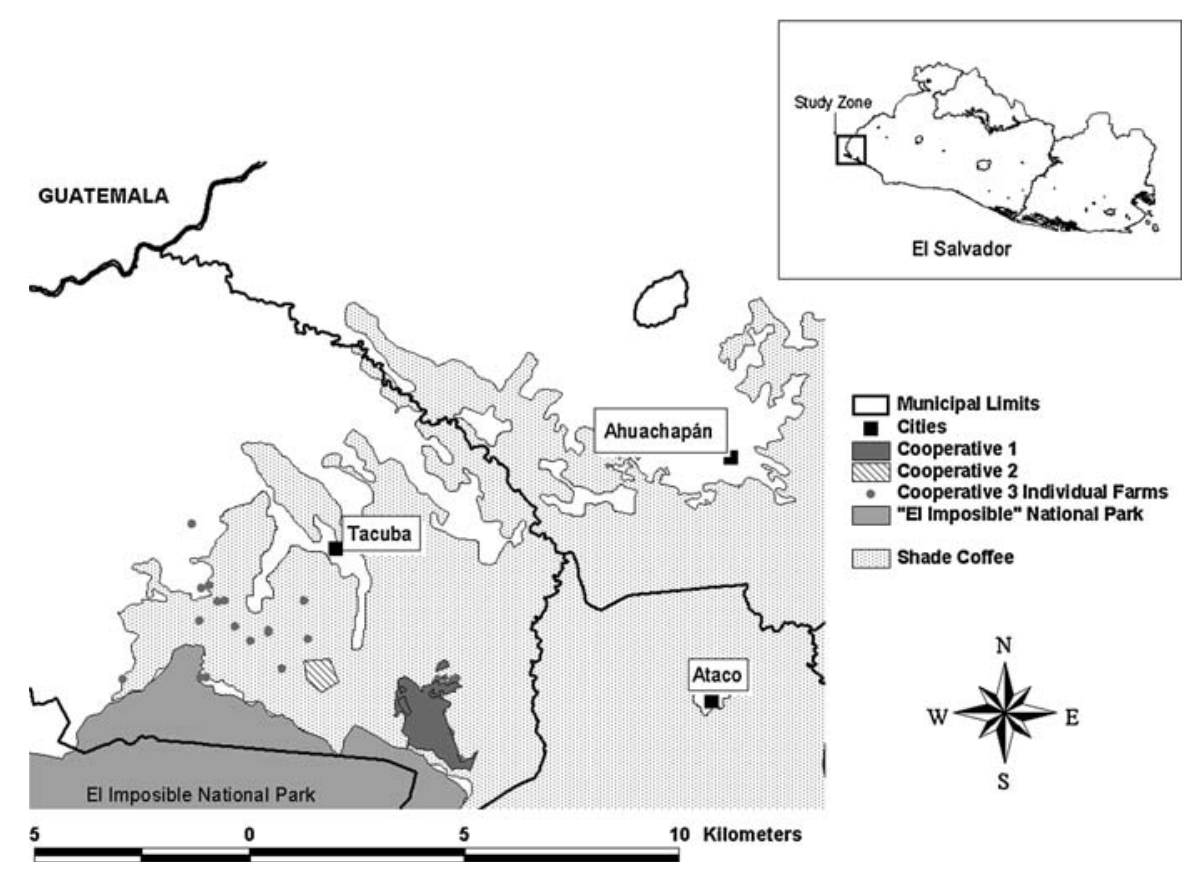


structured interviews with key informants between 2001 and 2002 (Méndez 2004). Semi-structured interviews (Leech 2002) on management histories and practices were conducted in 2002 with the individuals who had been directly responsible for management decisions for each quadrat (key informants). In Cooperatives 1 and 2, whose coffee plantations are collectively owned and managed, interviews were conducted with the head field managers from the previous 6 years. In Cooperative 3 , interviews were conducted with the owner of each individually owned and managed farm. Data collected included the total length of time the land had been under coffee cultivation, coffee yields for the 2001/2002 harvest, and the specific management practices used over the course of the previous 6 years. Surveys were complemented with four focus groups (Stewart et al. 2006). Three of these focus groups were conducted with the board of directors of each cooperative, and the last included selected members from all three cooperatives. Members that attended combined focus groups were selected through a two-step process: (1) Researchers requested attendance of specific members by name to the board of directors of the cooperative; and (2) The board of directors approved the researchers' request and instructed the selected members to attend the focus group. By the time the focus groups were conducted the researchers had an established 3-year relationship with the farmers. Thus, the board agreed with the choices of individuals we requested. Members were selected so as to provide a representative voice of the farmer cooperatives. We invited at least five members from each organization, two of which were from the board of directors, and three that were from the general membership. Individuals from the general membership were selected for their knowledge and ability to 'speak their mind'. For the combined meetings we avoided inviting members that could be intimidated by the interaction with other cooperatives and/or of expressing their opinions in front of their peers.

\section{Sampling quadrats}

Fifty-one 0.1-ha quadrats were located in the three cooperatives for a series of studies, starting in 2001 (see Fig. 1 for plot locations in the Tacuba landscape). Measurements taken in these quadrats included shade tree inventories (species richness, abundance, diameter at breast height (DBH) and height), photosynthetically active radiation (PAR) and leaf area index (LAI) with an AccuPAR ${ }^{\circledR} 8.0$ ceptometer or light meter (Decagon, Inc.), coffee plant densities, slope, and elevation. The ceptometer calculates LAI by measuring the difference between light levels above and below the canopy, and factoring in the leaf angle distribution, solar zenith angle, and plant extinction coefficient. PAR was used to calculate measures of percent shade cover. PAR and leaf area index measures were taken in the middle of the rainy (May-October), and dry (October-May) seasons, respectively. We did this because many of the trees that are present in this landscape are deciduous during the dry season so we expected to find significant differences in shade cover and LAI between seasons. For details on methods and results of these analyses see Méndez et al. (2007). Quadrats were located in Cooperatives 1 and 2 through a stratified random design within each cooperative (20 quadrats for Cooperative 1, and 14 for Cooperative 2). Stratification was based on a survey of each farm that identified shade types as described by Moguel and Toledo (1999). Cooperative 1 contained 3 shade types, and Cooperative 2 contained only one shade type. For Cooperative 3, 17 farms were randomly selected, and quadrats were placed in the middle of the coffee parcels of each farm.

\section{Soil sampling}

Soil samples were collected between June 2002 and March 2003 in the same 51 quadrats described above. A total of ten randomly selected points were sampled from each quadrat. Three types of samples were collected at each of the ten random sample points from within each quadrat. First, undecomposed organic litter was collected down to the soil level from within a $20 \times 20 \mathrm{~cm}$ square around each sample point, and placed in a Ziploc bag. Second, a sample to determine soil bulk density was collected using a density auger of $820-\mathrm{ml}$ volume and then placed in a sealable plastic container. Finally, samples for chemical analysis were taken using a tube auger of $2.54-\mathrm{cm}$ diameter. These core sample were then divided into sections according to depth: $0-10$, $10-20$, and $20-30 \mathrm{~cm}$. Soil from each of the ten 
sample points within each quadrat were combined to generate one composite sample for each depth.

Ecosystems services estimation

\section{Regulating services: $C$ stocks in the shade tree canopy}

We estimated the carbon stocks from the shade tree canopy in each cooperative using an allometric model based on tree height $(H)$, species-specific wood density $(\rho)$ and diameter at breast height $(D)$ from each of the trees recorded per cooperative in the 51 quadrats (a total of 2,743 trees). We used the following model proposed by Chave et al. (2005) to calculate total above ground biomass (AGB in $\mathrm{kg}$ ) for dry forest stands:

$$
\begin{aligned}
\operatorname{AGB}(\mathrm{kg}) & =\exp \left(-2.187+0.916 \times \ln \left(\rho D^{2} H\right)\right) \\
& \equiv 0.112 \times\left(\rho D^{2} H\right)^{0.916}
\end{aligned}
$$

where $\equiv$ is a mathematical identity explaining that both formulas can be used in the biomass estimation (Chave et al. 2005). To convert AGB to C stocks, we assumed a $\mathrm{C}$ content of $47 \%$ in each tree, as described by Kirby and Potvin (2007). Wood density data was obtained for 51 out of 123 species from the Wood Density Database maintained by the World Agroforestry Center (ICRAF 2008). For the remaining species we used the average of the mean wood density from the 51 species, which was $0.60 \mathrm{~g} \mathrm{~cm}^{-3}$ (following Chave et al. 2003). We calculated total C stocks (in $\mathrm{Mg}$ ) for each of the 51 plots $\left(1,000 \mathrm{~m}^{2}\right)$ and extrapolated this figure to $\mathrm{Mg} \mathrm{ha}^{-1}$.

\section{Provisioning services}

To assess provisioning services from the coffee plantations we examined coffee yields, the densities of different types of trees (fruit, firewood, timber, and windbreaks) and data from interviews related to shade tree use by species, and products that households obtained from shade trees ( $n=52$ households). In the surveys, farmers were asked to name and rank tree species and use in order of importance. This information was cross-checked with individuals known for their knowledge of trees. The inventories provided data on the number of individuals per use in each plot, which was then extrapolated to number of trees per ha. We used information from the interviews and the tree inventories to approximate the production potential of fruit, firewood, timber and medicinals in each cooperative.

Coffee yields were provided by cooperatives as pooled averages. Although these represent the final figures recorded for the 2001/2002 harvest, we were unable to measure yields at the plot level, which prevented us from including yield information in our statistical analyses.

\section{Laboratory analysis}

All field samples were processed and analyzed by the Analytical Services Laboratory of the Salvadoran Foundation for Coffee Research (Fundación Salvadoreña para Investigaciones del Café- PROCAFE) in San Salvador. Analytical approaches used to measure each trait are provided in Table 2.

\section{Statistical analyses}

Soil nutrients and physico-chemical characteristics were measured at three depths $(0-10,10-20$, and 20$30 \mathrm{~cm}$ ), but because the values for all attributes were highly correlated across depths within a nutrient (range $r=0.84-0.98$ for $\mathrm{pH}, \mathrm{N}, \mathrm{P}, \mathrm{K}, \mathrm{Ca}, \mathrm{Mg}, \mathrm{Al}$, total acidity, cation exchange capacity, and organic matter) we present only the results from the 0 to $10 \mathrm{~cm}$ sampling depth (Table 2). Differences among cooperatives in soil and agroeocosystem properties were analyzed through a one-way analysis of variance (ANOVA), and Tukey's HSD post-hoc test. Nitrogen content measurements from one quadrat in Cooperative 1 were clear outliers (greater than eight standard deviations above the mean) and likely reflected handling error, so this quadrat was eliminated from analyses of nitrogen.

We used MANOVA and discriminant analysis to compare soil chemical traits across the three cooperatives. Only those traits that were measured directly (rather than calculated from other measures, e.g., CEC) were included in the multivariate analyses $(\mathrm{pH}$, total acidity, organic matter, $\mathrm{N}, \mathrm{P}, \mathrm{K}, \mathrm{Ca}, \mathrm{Mg}, \mathrm{Al}$ ). We first tested for significant multivariate differences among cooperatives using a MANOVA. Given highly significant differences, we then used discriminant analysis to evaluate in what ways the cooperatives differed in soil traits. Backwards-selection stepwise 
discriminant analysis on the full dataset of 50 quadrats (the quadrat without $\mathrm{N}$ values was excluded from analysis) was used to choose which nutrients to include in the functions (retaining variables with $P \leq 0.10$ ). We then divided quadrats into two random groups within each cooperative. Half were used to train the discriminant functions using the selected traits, and the other half used for testclassification to evaluate the strength of differences among the cooperatives. This was done to avoid the problem of validating models with the same data used to parameterize them (Williams 1983).

Because there was a strong positive relationship between tree density and species richness (Richness $=3.69+18.32 \log _{10}($ stems $/$ ha $), R_{\text {adj }}^{2}=0.50$, $F_{1,49}=51.4, P \leq 0.0001$; Méndez et al. 2007), we evaluated the effect of tree species richness on soil properties (separate from the effect of tree density) by analysis of the residual terms from the above model for each plantation. The residual terms are by definition uncorrelated with $\log _{10}$ (density), and represent variation in species richness above or below that expected from a simple species-density relationship. We then used separate regressions to test for significant relationships between each soil parameter and either the $\log _{10}$ (Shade tree density) or the residual richness term. The first regression examines the confounded impacts of density and richness, whereas the regression against residuals examines the impacts of species richness per se.

Differences among cooperatives in the frequencies of tree uses reported in surveys were analyzed through a chi-square test. Analyses were performed using JMP v6.0 for Macintosh (SAS Institute, Inc., Cary NC) and SPSS v15 for Windows (SPSS, Inc., Chicago IL).

\section{Results}

Cooperative history and management approaches

The three cooperatives differed in their history, type of institutional arrangement, and management approaches (Table 1).

Cooperative 1 was formed through El Salvador's national agrarian reform in 1980. At this time, private plantations larger than 500 ha were expropriated by the government, and transferred to cooperatives created during the reform process, and made up of plantation workers and nearby community members. Farmers attempted to maintain the private plantation model, with a simplified shade canopy and high levels of external inputs, the dominant goal being increased coffee production. However, they were severely limited in achieving these goals by lack of capital and training as technical and financial support for cooperatives from the Salvadoran government after 1980 was inconsistent and problematic (Seligson 1995). Members of this cooperative did not hold a legal title to land, but are allocated plots within the cooperative to establish their residence and grow subsistence crops (Méndez 2004).

Cooperative 2 was formed by its members, and was able to utilize a window of opportunity created by the agrarian reform policy at the time, to obtain a loan and purchase their farm from a private owner. These farmers faced similar challenges to Cooperative 1 , in that they attempted to maintain a private plantation management model, but had more autonomy, and obtained individual land titles for their residential and subsistence crop plots. Cooperative 2 had a more efficient institutional structure and greater unity among members (Méndez 2004).

Cooperative 3 was the newest of the three, and represents a new model of production association promoted and legalized by El Salvador's Ministry of Agriculture in the 1990s. Each individual member owned his or her farm, but used the cooperative to commercialize their coffee and access other services and products collectively. These farmers maintained high levels of labor-intensive management even in times of economic hardship, though they often decreased capital-intensive practices such as pesticide or fertilizer application. Coffee production was the primary cash crop for these farmers, but they also obtained a higher diversity of subsistence products from their farms, which results in a strategy that maintained a shade canopy with more species and more trees (Méndez et al. 2007). The lesser emphasis on coffee production was also reflected in significantly lower frequency of coffee and shade tree pruning than the other two cooperatives.

Weeding and pruning of shade trees and coffee shrubs

All cooperatives employed similar management practices for weeding and pruning of coffee and 
Table 1 Characteristics of the origins, institutional types, and management in three coffee cooperatives of Tacuba, El Salvador

\begin{tabular}{|c|c|c|c|}
\hline \multirow[t]{2}{*}{ Characteristic } & \multicolumn{3}{|l|}{ Cooperative } \\
\hline & 1 & 2 & 3 \\
\hline $\begin{array}{l}\text { Total coffee area managed (both collective } \\
\text { and individual) (ha) }\end{array}$ & 195 & 35 & 21 \\
\hline Average farm size or area allocated per member & 2.0 & 2.5 & 0.7 \\
\hline Total number of households & 96 & 19 & 28 \\
\hline Tree biodiversity plots sampled $\left(1,000 \mathrm{~m}^{2}\right)$ & 20 & 14 & 17 \\
\hline Average $\%$ of land area in coffee & Estimate of 85 & 100 in collective plot & 90 \\
\hline Type of coffee plantation management & Collective & Collective & Individual \\
\hline $\begin{array}{l}\text { Tenure of land for residence } \\
\text { and subsistence crops }\end{array}$ & Collective & Individual & Individual \\
\hline Origin & $\begin{array}{l}\text { Agrarian reform transferred } \\
\text { to members by the state } \\
\text { (1980) }\end{array}$ & $\begin{array}{l}\text { Traditional cooperative } \\
\text { formed by members } \\
\text { (1984) }\end{array}$ & $\begin{array}{l}\text { Individual farmer } \\
\text { association (2001) }\end{array}$ \\
\hline
\end{tabular}

shade trees, but annual frequencies over a 6-year period were variable (Table 2). Frequency of shade tree pruning was significantly different among the three cooperatives. Coffee shrubs were pruned significantly less frequently in Cooperative 3 than in the other two cooperatives. Frequency of weeding did not differ among the three cooperatives. Frequency of coffee pruning had a significant positive correlation with percent organic matter $\left(r^{2}=0.15, P \leq 0.005\right)$ and percent total $\mathrm{N}\left(r^{2}=0.11, P \leq 0.015\right)$, and a significant negative correlation with $\mathrm{pH}\left(r^{2}=0.09\right.$, $P \leq 0.035)$. Frequency of shade tree pruning was positively correlated with dry litter weight $\left(r^{2}=0.23, P \leq 0.001\right)$ and $\mathrm{Ca}$ content $\left(r^{2}=0.10\right.$, $P \leq 0.025)$. No significant correlations were found between frequency of weeding and any soil property.

\section{Fertilizer management}

Farmers use fertilizer rates recommended by PROCAFE as a guide, although they are seldom able to apply at recommended rates because of high costs. Given the topography and planting arrangement in coffee plantations, fertilizers are usually applied in granular form on the soil surface surrounding the plant. For coffee shrubs over 3 years, PROCAFE recommends three fertilizer applications per year, using an NPK formula (15-15-15) for the first application, in May-June, of $0.113-0.170 \mathrm{~kg}$ per plant; and two additional Urea applications of 0.06$0.09 \mathrm{~kg}$ per plant in July/August and September/ October, respectively (Canjura and Sandoval 2003).
Cooperatives reported the number of applications of three different types of fertilizer-Urea $(46 \% \mathrm{~N})$, Formula (15\% N, 15\% $\mathrm{P}$ and $15 \% \mathrm{~K}$, respectively), and Ammonium Sulfate (21\% N and 24\% S) - over a 6 -year period (Table 2). The frequency of fertilizer applications differed significantly among cooperatives, and was considerably lower than the rates recommended by PROCAFE (Table 2, Canjura and Sandoval 2003). The amount of fertilizer per application reported by farmers was somewhat inconsistent, preventing us from calculating accurate total amounts from our interview data. As a general rule, farmers try to apply at least $32 \mathrm{~kg}$ of fertilizer per ha. In the case of the three cooperatives studied, with average coffee shrub densities of 6,095 per ha, this amounted to $0.007 \mathrm{~kg}$ per coffee shrub. This is much less than PROCAFE recommendations, especially considering that none of the cooperatives applied fertilizers on an annual basis. The only significant relationship we found between frequency of fertilizer application and soil nutrient content was a positive correlation between the number of applications of Formula and soil $\mathrm{P}\left(r^{2}=0.38, P \leq 0.006\right)$.

Soil and agroecosystem properties

All soil nutrients except $\mathrm{K}$ showed significant differences among cooperatives (Table 2), although the patterns of differences varied among nutrients. Soil properties collectively showed highly significant differences among the three cooperatives (MANOVA, Wilks' Lambda $=0.25, F_{18,78}=4.32, P \leq 0.0001$ ). 
Table 2 Soil (at a 0-10 cm depth), agroecosystem, and management properties for three farmer cooperatives of Tacuba, El Salvador

\begin{tabular}{|c|c|c|c|c|}
\hline Soil or agroecosystem properties & Coop $1(n=20)$ & Coop $2(n=14)$ & Coop $3(n=17)$ & $F$ ( $P$-value $)$ \\
\hline $\mathrm{pH}^{\mathrm{a}}$ & $4.85 \pm 0.45 \mathrm{~A}$ & $4.95 \pm 0.4 \mathrm{~A}$ & $5.49 \pm 0.42 \mathrm{~B}$ & $12.1(0.0001)$ \\
\hline $\mathrm{CEC}\left(\mathrm{meq} 100 \mathrm{ml}^{-1}\right)^{\mathrm{b}}$ & $13.29 \pm 5.25 \mathrm{~A}$ & $20.31 \pm 6.15 B$ & $21.36 \pm 5.09 \mathrm{~B}$ & $12.0(0.0001)$ \\
\hline Total acidity (meq $\left.100 \mathrm{ml}^{-1}\right)^{\mathrm{c}}$ & $5.12 \pm 2.00 \mathrm{~A}$ & $4.26 \pm 1.41 \mathrm{~A}$ & $2.51 \pm 0.79 \mathrm{~B}$ & $14.3(0.0001)$ \\
\hline Organic matter $(\%)^{\mathrm{d}}$ & $4.63 \pm 1.39 \mathrm{~A}$ & $4.62 \pm 1.49 \mathrm{AB}$ & $3.56 \pm 0.97 \mathrm{~B}$ & $3.8(0.030)$ \\
\hline Soil bulk density $(\mathrm{g})^{\mathrm{e}}$ & $1200.2 \pm 125.12 \mathrm{~A}$ & $1295.52 \pm 110.5 \mathrm{~B}$ & $1292.57 \pm 118.6 \mathrm{~B}$ & $4.4(0.017)$ \\
\hline Total $\mathrm{N}(\%)^{\mathrm{f}}$ & $0.38 \pm 0.09 \mathrm{~A}$ & $0.32 \pm 0.10 \mathrm{AB}$ & $0.27 \pm 0.08 \mathrm{~B}$ & $6.5(0.003)$ \\
\hline $\mathrm{P}(\mathrm{ppm})^{\mathrm{g}}$ & $8.39 \pm 8.65 \mathrm{~A}$ & $20.98 \pm 17.76 \mathrm{~B}$ & $10.26 \pm 10.4 \mathrm{AB}$ & $4.2(0.021)$ \\
\hline $\mathrm{K}(\mathrm{ppm})^{\mathrm{g}}$ & $317.05 \pm 85.75$ & $301.69 \pm 81.78$ & $259.33 \pm 127.58$ & $1.6(0.21)$ \\
\hline $\mathrm{Ca}(\mathrm{ppm})^{\mathrm{h}}$ & $9.69 \pm 4.87 \mathrm{~A}$ & $15.13 \pm 4.16 \mathrm{~B}$ & $16.42 \pm 3.87 \mathrm{~B}$ & $12.6(0.0001)$ \\
\hline $\operatorname{Mg}\left(\text { meq } 100 \mathrm{cc}^{-1}\right)^{\mathrm{h}}$ & $2.21 \pm 1.06 \mathrm{~A}$ & $3.83 \pm 1.77 \mathrm{~B}$ & $4.24 \pm 1.63 \mathrm{~B}$ & $9.9(0.0002)$ \\
\hline $\mathrm{Al}\left(\text { meq } 100 \mathrm{cc}^{-1}\right)^{\mathrm{h}}$ & $0.80 \pm 1.18 \mathrm{~A}$ & $0.27 \pm 0.28 \mathrm{AB}$ & $0.03 \pm 0.08 \mathrm{~B}$ & $5.0(0.010)$ \\
\hline$\%$ Shade cover (wet season) ${ }^{\mathrm{i}}$ & $58.65 \pm 20.71 \mathrm{~A}$ & $53.31 \pm 27.21 \mathrm{~A}$ & $78.21 \pm 12.49 \mathrm{~B}$ & $6.9(0.002)$ \\
\hline$\%$ Shade cover (dry season) ${ }^{\mathrm{i}}$ & $50.45 \pm 22.21$ & $38.39 \pm 19.12$ & $47.13 \pm 15.8$ & $1.6(0.22)$ \\
\hline Leaf area index (wet season) & $3.39 \pm 1.49 \mathrm{~A}$ & $1.66 \pm 1.00 \mathrm{~B}$ & $2.38 \pm 1.96 \mathrm{AB}$ & $5.3(0.008)$ \\
\hline Leaf area index (dry season) & $0.63 \pm 0.316$ & $0.66 \pm 0.420$ & $0.58 \pm 0.35$ & $2.2(0.800)$ \\
\hline Total tree richness ${ }^{\mathrm{i}}$ & $69 \pm 16.79 \mathrm{~A}$ & $48 \pm 11.16 \mathrm{~A}$ & $93 \pm 16.79 \mathrm{~B}$ & $15.02(0.0001)$ \\
\hline Tree species richness per quadrat ${ }^{\mathrm{i}}$ & $12 \pm 4.10 \mathrm{~A}$ & $12 \pm 2.89 \mathrm{~A}$ & $22 \pm 8.33 \mathrm{~B}$ & $15.22(0.0001)$ \\
\hline Tree density per quadrat ${ }^{\mathrm{i}}$ & $39 \pm 14.92 \mathrm{~A}$ & $35 \pm 16.15 \mathrm{~A}$ & $89 \pm 52.27 \mathrm{~B}$ & $14.81(0.0001)$ \\
\hline Coffee density per quadrat ${ }^{\mathrm{i}, \mathrm{j}}$ & $6077 \pm 1994$ & $5304 \pm 889$ & $6768 \pm 1828$ & $2.835(0.69)$ \\
\hline $\log _{10}\left(\right.$ trees ha $\left.{ }^{-1}\right)$ & $0.57 \pm 0.17 \mathrm{~A}$ & $0.44 \pm 0.19 \mathrm{~A}$ & $0.86 \pm 0.28 \mathrm{~B}$ & $15.7(0.0001)$ \\
\hline Residual species richness ${ }^{\mathrm{k}}$ & $-2.04 \pm 4.84 \mathrm{~A}$ & $0.60 \pm 2.43 \mathrm{AB}$ & $1.84 \pm 5.76 \mathrm{~B}$ & $3.31(0.05)$ \\
\hline Manual weeding ${ }^{1}$ & $10 \pm 2.70$ & $10.2 \pm 2.94$ & $9 \pm 3.82$ & $0.77(0.467)$ \\
\hline Coffee bush pruning ${ }^{1}$ & $1 \pm 0 \mathrm{~A}$ & $1 \pm 1.86 \mathrm{~A}$ & $0.56 \pm 2.59 \mathrm{~B}$ & $10.25(0.0001)$ \\
\hline Shade pruning ${ }^{1}$ & $1.6 \pm 1.19 \mathrm{~A}$ & $0.8 \pm 2.04 \mathrm{~B}$ & $0.53 \pm 2.28 \mathrm{C}$ & $14.60(0.0001)$ \\
\hline Urea $^{\mathrm{m}}$ & $1.02 \pm 1.32 \mathrm{~A}$ & $4.5 \pm 1.47 \mathrm{~B}$ & $2.3 \pm 2.03 \mathrm{~B}$ & $18.30(0.0001)$ \\
\hline Ammonium sulfate $^{\mathrm{m}}$ & $1.9 \pm 1.44 \mathrm{~A}$ & OB & $0.94 \pm 1.85 \mathrm{~B}$ & $7.62(0.001)$ \\
\hline 15-15-15 NPK formula ${ }^{\mathrm{m}}$ & $0.27 \pm 1.01 \mathrm{~A}$ & $4.17 \pm 1.2 \mathrm{~B}$ & $0.79 \pm 1.26 \mathrm{~A}$ & $52.03(0.0001)$ \\
\hline
\end{tabular}

Means $( \pm \mathrm{SD})$ followed by the same letter are not significant different by Tukey's HSD $(P=0.05)$

${ }^{a}$ Determined in $0.01 \mathrm{M} \mathrm{CaCl}_{2}$ solution using a potentiometer

b Sum of $\mathrm{Ca}, \mathrm{Mg}, \mathrm{K}$, and $\mathrm{Al}$

c Indirect SMP method using a potenciometer

d Walkley Black method

e Mass per volume of oven dry soil from composite of 820-ml auger samples

${ }^{\mathrm{f}}$ Keldal method using distillation and digestion with sulfuric acid

g North Carolina Mehlich method ( $\mathrm{P}$ using molybdenum blue clorometric and $\mathrm{K}$ using a photometer)

${ }^{\mathrm{h}}$ Extracted in $1 \mathrm{~N} \mathrm{KCl}$ solution ( $\mathrm{Ca}$ and $\mathrm{Mg}$ using an atomic absorbtion spectrophotometer; $\mathrm{Al}$ using titration)

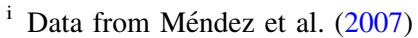

j Extrapolated to shrub density per ha

${ }^{\mathrm{k}}$ Residuals of regression of species richness on $\log 10$ (trees/ha), which represents deviation in species richness from that expected for that number of trees

${ }^{1}$ Mean annual frequency of practice over 6 years

${ }^{m}$ Number of fertilizer applications over 6 years 
Stepwise discriminant analysis indicated that five soil properties contributed to differentiating among the three cooperatives: $\mathrm{N}(P \leq 0.001), \mathrm{pH}(P \leq 0.0003)$, $\mathrm{P}(P \leq 0.078), \mathrm{K}(P \leq 0.093)$, and $\mathrm{Ca}(P \leq 0.004)$. Discriminant functions trained on a subset of quadrats successfully test-classified $80 \%$ of the remaining 25 quadrats to cooperative of origin, significantly better than the $36 \%$ expected by chance (Likelihood Ratio $\left.\chi^{2}=30.2, P \leq 0.0001\right)$. This indicates that despite large variability across the 51 quadrats there were strong patterns in soil properties that distinguished among the three cooperatives. Overall, farms on Cooperative 3 had more basic, calcium-rich soils, whereas farms on Cooperative 1 had greater levels of nitrogen and lower levels of phosphorus than those from other cooperatives. The canonical discriminant functions were: Canon $1=-6.862(\mathrm{~N})-0.189(\mathrm{pH})+0.047(\mathrm{P})$ $+0.002(\mathrm{~K})+0.289(\mathrm{Ca}) ; \quad$ Canon $2=0.076(\mathrm{~N})-$ $3.048(\mathrm{pH})+0.038(\mathrm{P})+0.008(\mathrm{~K})+0.212(\mathrm{Ca})$.

Effects of shade tree density and diversity on soil and agroecosystem properties

The three cooperatives also differed in terms of shade tree density and species richness (Table 2). The communally owned cooperatives ( 1 and 2 ), had significantly lower tree density, fewer tree species per quadrat, and lower total tree species richness, than did Cooperative 3. Because species richness increases with the number of trees in the quadrat (Méndez et al. 2007), analysis of tree diversity using richness per quadrat confounds the effects of density and richness. Residual analysis permits examining species richness per se-where a positive residual value indicates greater species richness than expected for the density of trees in the quadrat. Cooperative 1 had significantly lower tree species richness than expected, suggesting selection for a subset of species available in the overall pool, whereas Cooperative 3 had much greater diversity than expected, suggesting selection of a more diverse set of species than random (Fig. 2). Both of these cooperatives had greater quadrat-to-quadrat variation than did Cooperative 2, which consistently had about the level of diversity expected for a random selection of species at a particular density of individuals.

Shade-tree density strongly increased the amount of shade and leaf area during the wet season, but not during the dry season, when many shade trees are

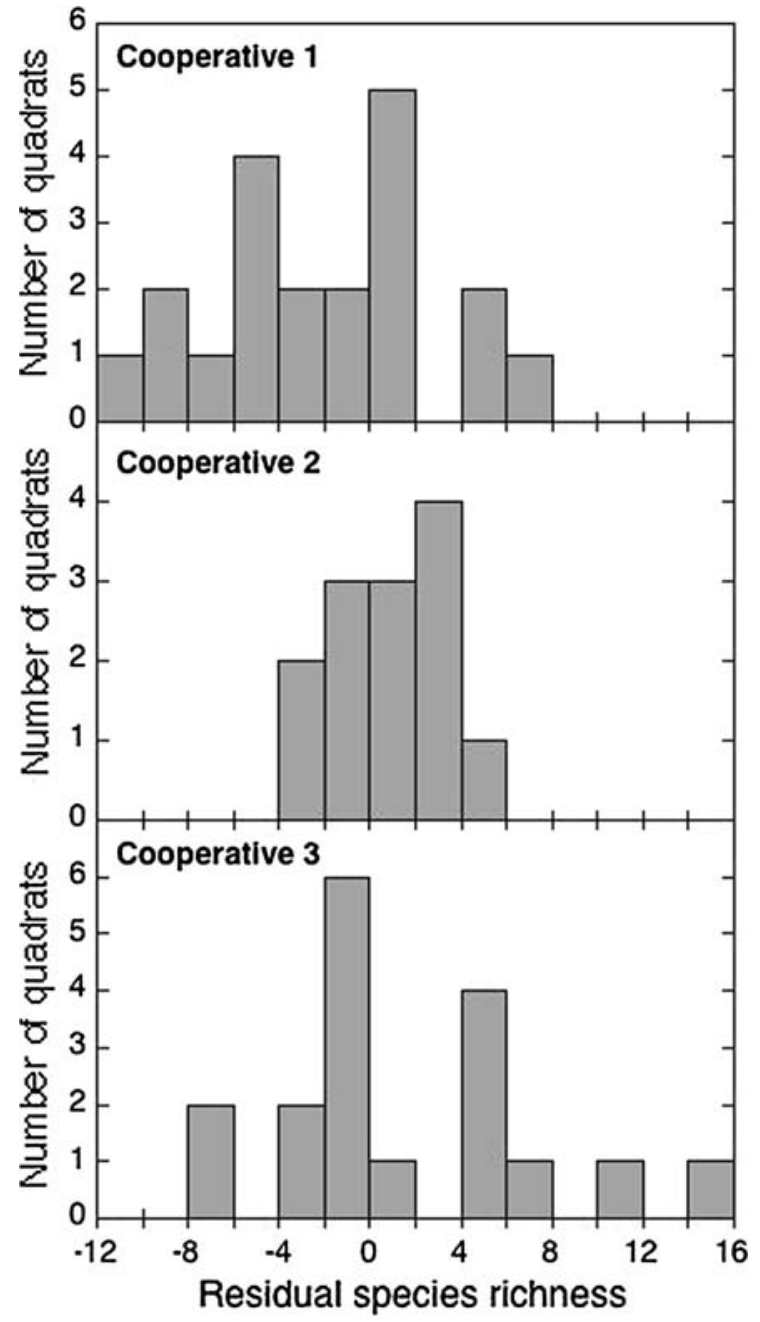

Fig. 2 Residual species richness of shade trees in quadrats sampled from three farmer cooperatives at Tacuba, El Salvador. Positive residual values indicate more species in the quadrat than expected for the number of trees in the quadrat

deciduous (Table 3; Fig. 3). Because of lower tree density, Cooperatives 1 and 2 had lower percent shade cover in the wet season than did Cooperative 3 (Table 2); wet season LAI was significantly lower in Cooperative 1 than either Cooperatives 2 and 3. In addition, increased tree density was associated with a significant decrease in organic matter and total $\mathrm{N}$, and with increased $\mathrm{pH}$ and $\mathrm{Mg}$ concentrations (Table 3). Variation in shade-tree species richness per se (independent of tree density) was closely correlated with variation in soil nutrient conditions; greater species richness was associated with increases in soil 
Table 3 Results of separate regressions of the effects of $\log 10$ (shade tree density), or of the residuals from the tree species richness versus $\log 10$ (tree density) regression on soil properties, shade density, and coffee harvest

\begin{tabular}{|c|c|c|c|c|c|c|c|c|c|c|}
\hline \multirow[t]{2}{*}{ Properties $^{\mathrm{a}}$} & \multicolumn{5}{|c|}{$\log _{10}($ Shade-tree density $)$} & \multicolumn{5}{|c|}{ Residual of richness vs. $\log 10$ (density) } \\
\hline & $R_{\mathrm{adj}}^{2}$ & $F_{1,49}^{\mathrm{b}}$ & $P$ & Intercept & Slope & $R_{\mathrm{adj}}^{2}$ & $F_{1,49}$ & $P$ & Intercept & Slope \\
\hline Shade (wet season) & 0.19 & 12.7 & 0.0008 & 40.71 & 36.89 & 0.02 & 0.08 & 0.78 & & \\
\hline Shade (dry season) & 0.02 & 0.03 & 0.86 & & & 0.01 & 0.43 & 0.51 & & \\
\hline Leaf area index (wet season) & -0.20 & 0.003 & 0.96 & & & 0.077 & 5.19 & 0.03 & 2.58 & -0.105 \\
\hline Leaf area index (dry season) & -0.020 & 0.005 & 0.95 & & & -0.004 & 0.803 & 0.37 & & \\
\hline Shade tree $\mathrm{C}$ stocks $\left(\mathrm{Mg} \mathrm{C}^{-1}\right)$ & 0.047 & 3.44 & 0.07 & & & 0.005 & 1.274 & 0.26 & & \\
\hline \# Fruit trees $\mathrm{ha}^{-1}$ & 0.35 & 27.4 & 0.0001 & -89.28 & 239.5 & 0.033 & 2.73 & 0.105 & & \\
\hline \# Firewood trees ha $^{-1}$ & 0.16 & 9.02 & 0.004 & -9.08 & 63.86 & -0.006 & 0.73 & 0.40 & & \\
\hline \# Timber trees $\mathrm{ha}^{-1}$ & 0.388 & 32.70 & 0.0001 & -124.57 & 339.86 & 0.114 & 7.4 & 0.009 & 91.77 & 10.90 \\
\hline \# Medicinal trees $\mathrm{ha}^{-1}$ & 0.239 & 16.68 & 0.0001 & -4.605 & 11.55 & 0.143 & 9.32 & 0.004 & 2.75 & 0.51 \\
\hline \# Windbreak trees $\mathrm{ha}^{-1}$ & 0.244 & 17.096 & 0.0001 & -75.24 & 315.96 & 0.284 & 20.83 & 0.0001 & 125.9 & -18.96 \\
\hline Organic matter (\%) & 0.07 & 4.79 & 0.03 & 8.62 & -2.47 & 0.01 & 0.46 & 0.50 & & \\
\hline $\mathrm{pH}$ & 0.06 & 4.04 & 0.05 & 4.78 & 0.51 & 0.07 & 4.62 & 0.04 & 5.10 & 0.03 \\
\hline Total acidity (meq $100 \mathrm{cc}^{-1}$ ) & 0.05 & 3.55 & 0.07 & & & 0.15 & 9.67 & 0.003 & 3.98 & -0.15 \\
\hline CEC (meq $100 \mathrm{cc}^{-1}$ ) & 0.04 & 3.13 & 0.08 & & & 0.09 & 5.61 & 0.02 & 17.80 & 0.42 \\
\hline $\mathrm{N}$ (total) $\%$ & 0.13 & 8.59 & 0.005 & 0.41 & -0.14 & 0.01 & 0.71 & 0.40 & & \\
\hline $\mathrm{P}(\mathrm{ppm})$ & 0.02 & 0.19 & 0.66 & & & 0.01 & 0.46 & 0.50 & & \\
\hline $\mathrm{K}(\mathrm{ppm})$ & 0.01 & 0.75 & 0.39 & & & 0.06 & 4.07 & 0.05 & 292.7 & -5.75 \\
\hline $\mathrm{Ca}(\mathrm{ppm})$ & 0.02 & 1.99 & 0.16 & & & 0.09 & 6.00 & 0.02 & 13.45 & 0.35 \\
\hline $\operatorname{Mg}\left(\right.$ meq $\left.100 \mathrm{cc}^{-1}\right)$ & 0.11 & 7.16 & 0.01 & 1.93 & 2.21 & 0.10 & 6.79 & 0.01 & 3.34 & 0.12 \\
\hline $\mathrm{Al}\left(\mathrm{meq} 100 \mathrm{cc}^{-1}\right)$ & 0.02 & 0.10 & 0.75 & & & 0.10 & 6.46 & 0.01 & 0.39 & -0.06 \\
\hline
\end{tabular}

a Soil nutrient and chemical properties are for $0-10 \mathrm{~cm}$ stratum

b Degrees of freedom for nitrogen are 1, 48

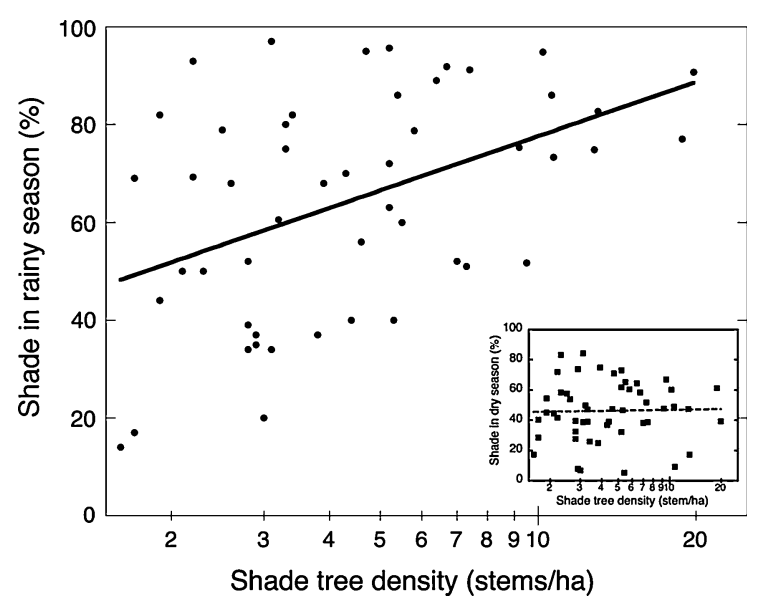

Fig. 3 Increased density of shade trees leads to greater shade during the rainy season (Shade $=40.7+36.9 \log _{10}$ (stems/ha), $R_{\text {adj }}^{2}=0.19, F_{1,49}=12.7, P=0.0008$ ), but not during the dry season when many trees are deciduous (insert; $R_{\text {adj }}^{2}=0.02$, $F_{1,49}=0.79, P=0.71$ )
$\mathrm{pH}, \mathrm{CEC}, \mathrm{Ca}$, and $\mathrm{Mg}$, and decreases in $\mathrm{Al}, \mathrm{K}$, and total acidity (Table 3 ).

In addition to the variation in tree density and diversity across cooperatives, shade-tree density was affected by geographic location. Sites closer to El Imposible National Park (PNEI) $\left(r^{2}=0.08\right.$, $\left.F_{1,49}=5.21, \quad P \leq 0.027\right), \quad$ at higher elevation $\left(r^{2}=0.16, F_{1,49}=10.56, P \leq 0.027\right)$ and on steeper slopes $\left(r^{2}=0.20, F_{1,49}=13.81, P \leq 0.0005\right)$ had higher total density of trees. Because species richness increases with tree density, sites with high elevation, steep slope, and proximity to the park also supported the greatest diversity of shade tree species. Residual analysis indicated that the greater diversity was a simple function of the greater number of shade trees in such sites, with no additional effect of geography on tree diversity $(P>0.19$ for regressions with distance to PNEI, elevation, or slope). 
Table 4 Provisioning and regulating ecosystem services in three farmer cooperatives of Tacuba, El Salvador

\begin{tabular}{|c|c|c|c|c|}
\hline Ecosystem service & Coop $1(n=20)$ & Coop $2(n=14)$ & Coop $3(n=17)$ & $F(P$-value $)$ \\
\hline \multicolumn{5}{|l|}{ Provisioning } \\
\hline Coffee yields $\left(\mathrm{kg} \mathrm{ha}^{-1}\right)$ & 465.35 & 333.69 & 69.62 & NA \\
\hline \# Fruit trees ha ${ }^{-1 \mathrm{a}}$ & $10 \pm 18.20 \mathrm{~A}$ & $21 \pm 24.33 \mathrm{~A}$ & $162 \pm 148.46 \mathrm{~B}$ & $16.24(0.0001)$ \\
\hline \# Firewood trees ha ${ }^{-1}$ & $14 \pm 13.48 \mathrm{~A}$ & $29 \pm 25.07 \mathrm{AB}$ & $55 \pm 67.46 \mathrm{~B}$ & $4.61(0.015)$ \\
\hline \# Timber trees $\mathrm{ha}^{-1}$ & $18 \pm 21.90 \mathrm{~A}$ & $47 \pm 39 \mathrm{~A}$ & $215 \pm 206.46 \mathrm{~B}$ & $13.37(0.0001)$ \\
\hline \# Medicinal trees $\mathrm{ha}^{-1}$ & $2 \pm 3.66$ & $1 \pm 2.67$ & $6 \pm 9.39$ & $3.49(0.38)$ \\
\hline \# Windbreak trees ha ${ }^{-1}$ & $158 \pm 153.96$ & $71 \pm 123.8$ & $134 \pm 219$ & $1.08(0.35)$ \\
\hline \multicolumn{5}{|l|}{ Regulating } \\
\hline Shade tree $\mathrm{C}$ stocks $\left(\mathrm{Mg} \mathrm{C}^{-1}\right)$ & $17.79 \pm 10.88$ & $12.40 \pm 4.81$ & $19.39 \pm 12.59$ & $1.9(0.160)$ \\
\hline
\end{tabular}

Means followed by the same letter are not significantly different by Tukey's HSD $(P=0.05)$

${ }^{a}$ We used the densities of trees for specific uses as an approximation for the production potential of provisioning services other than coffee in the plantation

Interactions between cooperative management and ecosystem services

The effects of management on the shade tree canopy composition and soil properties did not significantly affect the level of $\mathrm{C}$ stocks between the three cooperatives (Table 4). We also did not find a significant association between $\mathrm{C}$ stocks and either tree density or tree species richness (Table 3).

Reported average coffee yields were 4.8- and 6.7times greater in Cooperatives 1 and 2, respectively, than in Cooperative 3 (Table 4), but because the values were aggregated across the entire cooperative, we were not able to analyze these statistically.

The mean number of fruit, firewood and timber trees per ha were significantly different between the three cooperatives (Table 4). Cooperative 3 had a significantly greater number of fruit and timber trees than the other two cooperatives, while Cooperatives 1 and 2 did not differ significantly. Abundance of firewood trees was also higher in Cooperative 3, and significantly different from Cooperative 1, but not from Cooperative 2. No significant differences were observed for mean number of trees used for medicinal purposes or windbreaks.

Household surveys showed differences in the frequency of use of tree products (Méndez 2008). All Cooperative 3 members interviewed reported that they obtained fruit from their shade coffee plantations $(n=17)$, as compared to 84 and $40 \%$ in cooperatives 1 $(n=25)$ and $2(n=10)$. For fruit trees we found reports consistent with the tree abundance by use data discussed in the previous paragraph; cooperatives with more fruit trees (3 and 2) more often reported fruit trees as an important provisioning service. This was not the case for other uses. Firewood harvesting was most commonly reported in Cooperative $1(96 \%)$, followed by Cooperatives $2(90 \%)$ and $3(77 \%)$. Although Cooperative 1 had fewer trees that are used for firewood, most of the members interviewed reported harvesting this product. Timber harvesting was most common in responses from Cooperative $2(70 \%)$, followed by Cooperatives 3 (44\%) and 2 (20\%), respectively. Less than half of the members interviewed in Cooperative 3 reported harvesting timber, even though they had a significantly higher number of timber trees than Cooperatives 2 and 3. Although the frequencies of responses for tree uses were dissimilar for the three cooperatives, a chi-square test on the association between tree use and cooperative type showed no statistically significant differences $\left(\chi^{2}=1.62, d f=4, P<0.080\right)$.

The density of trees for firewood, timber, medicinal use, and windbreak each increased significantly with increasing overall shade-tree density (Table 3 ). On the other hand, higher overall tree species richness increased the abundances of timber, medicinal, and windbreak species (Table 3).

\section{Discussion}

Institutional history

There was a marked difference in management approaches between the collectively managed 
cooperatives that had once been private plantations (1 and 2) and the cooperative of associated small-scale farms. The collectively managed cooperatives tried to maintain a commercial plantation model with a less diverse shade canopy, with their primary goal being increased coffee production. They did achieve severalfold greater coffee yield than did individual farmers, but at the same time had significantly lower levels of tree species and tree abundance. Cooperatives 1 and 2 also demonstrated significantly higher frequency of coffee bush and shade tree pruning than Cooperative 3 . The farmers of the individually managed farms of Cooperative 3, who sought to obtain a higher diversity of products from their farms, chose to maintain a shade canopy with more shade trees and a greater diversity of tree species, and to invest less labor into coffee production than Cooperatives 1 or 2 .

\section{Agroecosystem properties}

Differences in cooperative type had an effect on management practices, such as shade tree species richness and density, and frequency of shade tree and coffee bush pruning. Weeding frequency did not differ significantly among the cooperatives, suggesting that this practice is given equal priority, independent of institutional characteristics or management approach. In all three cooperatives shade tree density was affected by topography, with an increased number of trees in higher and steeper locations.

A common concern in intensive input coffee production is the acidification of soils caused by the application of chemical fertilizers. Acidification can lead to high levels of aluminum that become toxic to coffee plants. In contrast, although we found that the type and frequency of application rates varied between cooperatives, the total quantity of fertilizer applied was so relatively small as to have little to no impact on soil properties. That there was a positive correlation between frequency of the application of Formula (which contains $\mathrm{P}$ ), and total soil $\mathrm{P}$ is not surprising, given that $\mathrm{P}$ is relatively immobile. The optimal soil nutrient content and recommended fertilizer rates as described by PROCAFE, the leading coffee research institute in the country, make evident the large disconnect between these technical recommendations and the reality of small-scale farmers. In addition, it points to the need for research that can better inform farmers that specifically manage lowinput, diversified shade coffee agroecosystems.

Shade tree composition and management affected soil nutrient content and properties. Higher tree species richness was associated with higher soil $\mathrm{pH}$, CEC, calcium, and magnesium levels, but decreased total K. Previous studies have suggested that shade with high species richness provides leaf litter with more balanced nutrient content (Mendoca and Stott 2003), increases earthworm density (Hairiah et al. 2006) and, through the fuller occupation of soil volume, may reduce nutrient leaching and increase the recycling of sub-soil nutrients. We found reduced total nitrogen and soil organic matter, and increased $\mathrm{pH}$, to be associated with higher tree density. These findings contradict Romero-Alvarado et al. (2002), who found no correlations between shade tree density and diversity and soil nutrient content, $\mathrm{pH}$ levels or coffee yields. In contrast, Gillison et al. (2004) found strong correlation between species richness and plant functional types (PFT) or guilds, and soil conditions. This seems in line with some of our results on the effects of tree density over certain soil properties (organic matter, total $\mathrm{N}$, and $\mathrm{pH}$ and $\mathrm{Mg}$ concentrations), although we did not analyze community composition by guild or type.

Frequency of shade tree and coffee shrub pruning also affected soil properties. Higher frequencies of coffee bush pruning were shown to be positively correlated with percent total $\mathrm{N}$ and negatively correlated with $\mathrm{pH}$. Frequency of shade tree pruning was positively correlated with dry litter weight and calcium content. These results are consistent with the general findings of previous research that show additions of fresh organic matter increased $\mathrm{pH}$ in tropical soils (Wong et al. 2000) and can contribute considerable amounts of N (Beer et al. 1998).

We found no significant difference in frequency of weeding between the three cooperatives, which prohibits us from drawing conclusions on the effect of weeding on soil properties. Farmer interviews revealed that no herbicides had been applied in the previous 6 years and that the majority of the plots had been weeded using a technique known locally as 'peina blanca' that leaves the weed roots in the ground along with a significant portion of the weed stems. Coffee plantation weeding practices that either leave weeds intact or leave a significant portion of the stem and roots have been reported to have strong 
impacts on increasing soil organic matter and soil nutrients, and decreasing rates of soil erosion, acidification, and exchangeable aluminum (Pavan et al. 1995; Afrifa et al. 2003; Sarno et al. 2004). From these studies we can infer that weeding practices in the three cooperatives have likely had a positive impact on soil properties, but we cannot determine the extent.

It is difficult in an observational study to evaluate the relative contribution of management practices and natural geographic variation on differences in soil nutrients among the three cooperatives. The farms in our study were widely distributed spatially (quadrats in Cooperative 1 are distributed across a land area greater than Cooperatives 2 and 3 combined), and we also recognize the great spatial and temporal variability in soil properties found under natural conditions. However, because the discriminant function was able to accurately differentiate among samples from the different cooperatives, despite the great geographic distribution of farms, we believe that management approaches were the primary agents driving differences in soils across the cooperatives. Long-term randomized experiments, with before-and-after soil evaluations, would be the logical next step.

\section{Ecosystem services}

Although plot- or shrub-based data are not available to assess the significance of the effects of different shade and management practices on coffee yields, our findings suggest that a diversified and relatively dense tree canopy has mixed effects on nutrients and other soil properties. An important finding was that higher shade tree densities were associated with lower levels of total N, K, and organic matter, which are factors that could affect coffee plant development and soil structure. This suggests that higher shade tree densities may result in competitive effects between trees and coffee shrubs. Our contradictory findings, concerning the effects of shade trees on soil properties, point to the need for further research in order to better understand the complex biophysical interactions occurring in these plantations. Important questions include: identifying optimal tree densities; teasing out the effects of species composition; and testing the use of plant functional types, as proposed by Gillison et al. (2004). All of these variables need to be directly assessed in terms of coffee yield and the socioeconomic priorities of growers, in order to provide insight that can both inform research and prove useful to farmers.

Although we found differences in the incidence of various provisioning services (e.g., fruit, timber, firewood, medicinal or windbreaks) between the cooperatives, it is clear that in all cases the coffee plantations were managed to produce a wide variety of products other than coffee. The significantly higher number of fruit and timber trees and lower coffee yields are yet another indication that the management strategy of Cooperative 3 is designed both for production of these secondary products as well as coffee. Of note is that above ground carbon stocks were similar regardless of differences in management strategy employed by the cooperatives.

\section{Conclusions}

Our results suggest the history of cooperatives, as well as their institutional and land tenure arrangements can influence management strategies and practices. In our study, these management approaches had mixed effects on agroecosystem properties and ecosystem services. Collectively managed cooperatives had a lower density and diversity of shade trees. This had varied effects on soil properties, but no effects on $\mathrm{C}$ stocks. On the other hand, it did affect the production potential of fruit, firewood and timber. In our particular case, cooperatives of independent farmers conserved more tree biodiversity, which in turn offered the potential to provide more provisioning services. However, this was done at a cost in coffee yields. This shows a conflict between diversification of provisioning services and yields of the main agricultural product. No differences were observed between $\mathrm{C}$-stocks in the three cooperatives, which suggests that a range of tree densities and sizes may yield similar levels of sequestered $C$. The distinct management approaches differentially affected soil nutrient content and properties. Increased species richness was correlated with higher levels of important nutrients while increased density was related to both lower nutrient levels and soil organic matter.

Programs that seek to support shade coffee cooperatives to conserve and manage multiple ecosystem services should take cooperative types and management 
approaches into consideration as a factor in project design. Different management strategies may require distinct types of support and intervention. In our study, cooperatives of independent farmers could benefit from technical support to improve coffee yields in a way that maintains the high levels of shade tree diversity already present. Collective cooperatives would gain from increasing other provisioning services (e.g., fruit) through shade diversification. Working with farmer cooperatives, rather than with individual farms, may facilitate achieving landscape-scale results in terms of ecosystem services conservation and management (see for example Franks and Mcgloin 2007).

Our study corroborates the importance of carrying out analyses that integrate biophysical and social information (in our case cooperative institutional arrangements and history) that allow for more comprehensive and interdisciplinary research. An increasing number of investigations that have utilized this approach have provided important contributions to our understanding of the complex social and ecological context in which tropical shade coffee agroecosystems exist (e.g., Gillison et al. 2004; Potvin et al. 2005; Gordon et al. 2007; Soto-Pinto et al. 2007; Bacon et al. 2008; Guadarrama-Zugasti 2008; Trujillo 2008). These integrated studies can provide useful information to guide policy makers and farmers in their efforts to develop shade coffee landscapes and institutional systems that adequately manage and conserve a variety of ecosystem services.

Acknowledgments $\mathrm{We}$ are grateful to the members and boards of directors of the three coffee cooperatives in El Salvador. Luis Ramírez and Mac Sandoval provided invaluable field research support. Dr. Florencia Montagnini provided advice and guidance in the early stages of the research. We thank Meryl Olson for her assistance in C stocks calculations. The first author received financial support from the VavilovFrankel Fellowship, the Conservation, Food and Health Foundation and the Center for Tropical Ecology, Agriculture and Development (CENTREAD) at the University of California, Santa Cruz. The second author received financial support from the Tinker Foundation, the Heinz Family Philanthropies, the Yale University Tropical Resources Institute, Program in Agrarian Studies, and Center for International and Area Studies.

Open Access This article is distributed under the terms of the Creative Commons Attribution Noncommercial License which permits any noncommercial use, distribution, and reproduction in any medium, provided the original author(s) and source are credited.

\section{References}

Afrifa AA, Ofori-Frimpong K, Appiah MR et al (2003) Effects of mulching on soil nutrients and yield of Robusta coffee. Trop Agric 80:105-109

Ataroff M, Monasterio M (1997) Soil erosion under different management of coffee plantations in the Venezuelan Andes. Soil Technol 11:95-108. doi:10.1016/S0933-3630 (96)00118-3

Babbar LI, Zak DR (1994) Nitrogen cycling in coffee agroecosystems: net $\mathrm{N}$ mineralization and nitrification in the presence and absence of shade trees. Agric Ecosyst Environ 48:107-113. doi:10.1016/0167-8809(94)90081-7

Babbar LI, Zak DR (1995) Nitrogen loss from coffee agroecosystems in Costa Rica-leaching and denitrification in the presence and absence of shade trees. J Environ Qual 24: 227-233

Bacon C (2005) Confronting the coffee crisis: can fair trade, organic and specialty coffees reduce small-scale farmer vulnerability in northern Nicaragua. World Dev 33:497511. doi:10.1016/j.worlddev.2004.10.002

Bacon CM, Méndez VE, Gliessman SR et al (eds) (2008) Confronting the coffee crisis: fair trade, sustainable livelihoods and ecosystems in Mexico and Central America. MIT Press, Cambridge

Bebbington A (1996) Organizations and intensificationscampesino federations, rural livelihoods and agricultural technology in the Andes and Amazonia. World Dev 24: 1161-1177. doi:10.1016/0305-750X(96)00028-9

Bebbington A (1997) Social capital and rural intensification: local organizations and islands of sustainability in the rural Andes. Geogr J 163:189-197. doi:10.2307/3060182

Beer J (1987) Advantages, disadvantages and desirable characteristics of shade trees for coffee, cocoa and tea. Agrofor Syst 5:3-13. doi:10.1007/BF00046410

Beer J (1988) Litter production and nutrient cycling in coffee (Coffea-arabica) or Cacao (Theobroma-cacao) plantations with shade trees. Agrofor Syst 7:103-114. doi:10.1007/ BF00046846

Beer J, Muschler R, Kass D et al (1998) Shade management in coffee and cacao plantations. Agrofor Syst 38:139-164. doi:10.1023/A:1005956528316

Canjura M, Sandoval J (2003) Fertilizacion del cafeto. In: PROCAFE (ed) Manual del caficultor 2003. Fundacion Salvadoreña para Investigaciones del Café (PROCAFE). Nueva San Salvador, El Salvador, pp 34-48

Carpenter SR, DeFries R, Dietz T et al (2006) Millennium ecosystem assessment: research needs. Science 314:257258. doi: $10.1126 /$ science. 1131946

Chave J, Condit R, Lao S et al (2003) Spatial and temporal variation of biomass in a tropical forest: results from a large census plot in Panama. J Ecol 91:240-252. doi: 10.1046/j.1365-2745.2003.00757.x

Chave J, Andalo C, Brown S et al (2005) Tree allometry and improved estimation of carbon stocks and balance in tropical forests. Oecologia 145:87-99. doi:10.1007/s00442-005-0100-x

Costanza R, D'Arge R, de Groot R et al (1997) The value of the world's environmental services and natural capital. Nature 387:253-260. doi:10.1038/387253a0 
Dietsch TV, Philpott SM, Rice RA et al (2004) Conservation policy in coffee landscapes. Science 303:625-626. doi: 10.1126/science.303.5658.625b

Escamilla P, Díaz S (2002) Sistemas de cultivo de café en México. Universidad Autónoma de Chapingo \& Fundación Produce, Huatusco, Ver., México

Flores M, Bratescu A, Martínez JO et al (2002) Centroamérica: el impacto de la caída de los precios del café. CEPAL/ ECLAC, México

Fox J (1992) Democratic rural development: leadership accountability and regional peasant organizations. Dev Chang 23:1-36. doi:10.1111/j.1467-7660.1992.tb00444.x

Franks JR, McGloin A (2007) Environmental co-operatives as instruments for delivering across-farm environmental and rural policy objectives: lessons for the UK. J Rural Stud 23(4):472-489. doi:10.1016/j.jrurstud.2007.03.002

Gillison AN, Liswanti N, Budidarsono S et al (2004) Impact of cropping methods on biodiversity in coffee agroecosystems in Sumatra, Indonesia. Ecol Soc 9:7. [online] http:// www.ecologyandsociety.org/vol9/iss2/art7

Gordon C, Manson R, Sundberg J et al (2007) Biodiversity, profitability, and vegetation structure in a Mexican coffee agroecosystem. Agric Ecosyst Environ 118:256-266. doi: 10.1016/j.agee.2006.05.023

Greenberg R, Bichier P, Angon AC et al (1997) Bird populations in shade and sun coffee plantations in Central Guatemala. Conserv Biol 11:448-459. doi:10.1046/j.1523-1739.1997. 95464.x

Guadarrama-Zugasti C (2008) A grower typology approach to assessing the environmental impact of coffee farming in Veracruz, Mexico. In: Bacon CM, Méndez VE, Gliessman SR et al (eds) Confronting the coffee crisis: fair trade, sustainable livelihoods and ecosystems in Mexico and Central America. MIT Press, Cambridge, pp 127-154

Hairiah K, Sulistyani H, Suprayogo D (2006) Litter layer residence time in forest and coffee agroforestry systems in Sumberjaya, West Lampung. For Ecol Manag 224:45-57. doi:10.1016/j.foreco.2005.12.007

Hoyos N, Comerford NB (2005) Land use and landscape effects on aggregate stability and total carbon of Andisols from the Colombian Andes. Geoderma 129:268-278. doi: 10.1016/j.geoderma.2005.01.002

ICRAF (World Agroforestry Center) (2008) Wood density database. http://www.worldagroforestry.org/sea/Products/ AFDbases/WD/Index.htm. Accessed 5 Feb 2009

Kirby KR, Potvin C (2007) Variation in carbon storage among tree species: implications for the management of a smallscale carbon sink project. For Ecol Manag 246:208-221. doi:10.1016/j.foreco.2007.03.072

Leblanc HA, McGraw RL, Nygren P (2007) Dinitrogen-fixation by three neotropical agroforestry tree species under semi-controlled field conditions. Plant Soil 291:199-209. doi:10.1007/s11104-006-9186-0

Leech BL (2002) Asking questions: techniques for semistructured interviews. PS Polit Sci Polit 35:665-668

MA (Millennium Ecosystem Assessment) (2003) Ecosystems and human well-being: a framework for assessment. Island Press, Washington, DC

MARN (2003) Mapas del Sistema de Información Ambiental. Ministerio de Medio Ambiente y Recursos Naturales (MARN), El Salvador
Méndez VE (2004) Traditional shade, rural livelihoods, and conservation in small coffee farms and cooperatives of western El Salvador. Ph.D. Dissertation, Department of Environmental Studies, University of California, Santa Cruz

Méndez VE (2008) Farmers' livelihoods and biodiversity conservation in a coffee landscape of El Salvador. In: Bacon CM, Méndez VE, Gliessman SR et al (eds) Confronting the coffee crisis: fair trade, sustainable livelihoods and ecosystems in Mexico and Central America. MIT Press, Cambridge, pp 207-236

Méndez VE, Gliessman SR, Gilbert GS (2007) Tree biodiversity in farmer cooperatives of a shade coffee landscape in western El Salvador. Agric Ecosyst Environ 119:145159. doi:10.1016/j.agee.2006.07.004

Mendoca EC, Stott DE (2003) Characeristics and decomposition rates of pruning residues from a shaded coffee system in Southeastern Brazil. Agrofor Syst 57:117-125. doi: 10.1023/A:1023900822261

Mogollón JP, García-Miragaya J, Sánchez LF et al (1997) Nitrógeno potencialmente disponible en suelos cafetales bajo diferentes árboles de sombra. Agronomia Trop 47:87-102

Moguel P, Toledo VM (1999) Biodiversity conservation in traditional coffee systems of Mexico. Conserv Biol 13: 11-21. doi:10.1046/j.1523-1739.1999.97153.x

Murray D, Raynolds LT, Taylor PL (2003) One cup at a time: poverty alleviation and fair trade coffee in Latin America. Colorado State University/CIESAS/Desarrollo Alternativo, Fort Collins

Nestel D (1995) Coffee in Mexico: international market, agricultural landscape and ecology. Ecol Econ 15:165-178. doi:10.1016/0921-8009(95)00041-0

Pavan MA, Chaves JCD, Androcioli Filho A et al (1995) Soil aggregation changes in coffee plantations as affected by management. Arq Biol Tecnol 38:205-215

Payan F, Jones DL, Beer J (2007) Dynamics of size-density fractions of soil organic matter following the addition of tree litter to organic coffee farms. Geoderma 141:15-22. doi:10.1016/j.geoderma.2007.02.017

Peeters LYK, Soto-Pinto L, Perales H et al (2003) Coffee production, timber, and firewood in traditional and Inga-shaded plantations in Southern Mexico. Agric Ecosyst Environ 95:481-493. doi:10.1016/S0167-8809(02)00204-9

Perfecto I, Vandermeer J (2002) Quality of agroecological matrix in a tropical montane landscape: ants in coffee plantations in Southern Mexico. Conserv Biol 16:174-182. doi:10.1046/j.1523-1739.2002.99536.x

Perfecto I, Rice RA, Greenberg R et al (1996) Shade coffee: a disappearing refuge for biodiversity. Bioscience 46:598609. doi:10.2307/1312989

Perfecto I, Mas A, Dietsch T et al (2003) Conservation of biodiversity in coffee agroecosystems: a tri-taxa comparison in southern Mexico. Biodivers Conserv 12:12391252. doi:10.1023/A:1023039921916

Philpott SM, Dietsch T (2003) Coffee and conservation: a global context and the value of farmer involvement. Conserv Biol 17:1844-1846. doi:10.1111/j.1523-1739. 2003.00150.x

Potvin C, Owen CT, Melzi S et al (2005) Biodiversity and modernization in four coffee-producing villages of Mexico. Ecol Soc 10:18. [online] http://www.ecologyand society.org/vol10/iss 1/art18 
Redel YD, Rubio R, Rouanet JL et al (2007) Phosphorus bioavailability affected by tillage and crop rotation on a Chilean volcanic derived Ultisol. Geoderma 139:388-396. doi:10.1016/j.geoderma.2007.02.018

Rice PD, McLean J (1999) Sustainable coffee at the crossroads. Consumer's Choice Council, Washington, DC

Romero-Alvarado Y, Soto-Pinto L, Garcia-Barrios L et al (2002) Coffee yields and soil nutrients under the shades of Inga sp vs. multiple species in Chiapas, Mexico. Agrofor Syst 54:215-224. doi:10.1023/A:1016013730154

Sarno, Lumbanraja J, Afandi et al (2004) Effect of weed management in coffee plantation on soil chemical properties. Nutr Cycl Agroecosyst 69:1-4. doi:10.1023/ B:FRES.0000025309.62716.13

Schroth G, Lehmann J, Rodrigues MRL et al (2001) Plant-soil interactions in multistrata agroforestry in the humid tropics. Agrofor Syst 53:85-102. doi:10.1023/A:1013360 000633

Schroth G, da Fonseca GAB, Harvey CA et al (eds) (2004) Agroforestry and biodiversity conservation in tropical landscapes. Island Press, Washington, DC

Segura M, Kanninen M, Suarez D (2006) Allometric models for estimating aboveground biomass of shade trees and coffee bushes grown together. Agrofor Syst 68:143-150. doi:10.1007/s10457-006-9005-x

Seligson MA (1995) Thirty years of transformation in the agrarian structure of El Salvador, 1961-1991. Lat Am Res Rev 30:43-74

Siebert SF (2002) From shade- to sun-grown perennial crops in Sulawesi, Indonesia: implications for biodiversity conservation and soil fertility. Biodivers Conserv 11:18891902. doi:10.1023/A:1020804611740

Somarriba E (1990) Sustainable timber production from uneven-aged shade stands of Cordia alliodora in small coffee farms. Agrofor Syst 10:253-263. doi:10.1007/ BF00122915

Somarriba E, Harvey C, Samper M (2004) Biodiversity in coffee plantations. In: Schroth G, da Fonseca GAB, Harvey CA et al (eds) Agroforestry and biodiversity conservation in tropical landscapes. Island Press, Washington, DC, pp 198-226

Soto-Pinto L, Perfecto I, Castillo-Hernandez J et al (2000) Shade effect on coffee production at the northern Tzeltal zone of the state of Chiapas, Mexico. Agric Ecosyst Environ 80:61-69. doi:10.1016/S0167-8809(00)00134-1

Soto-Pinto L, Villalvazo-Lopez V, Jimenez-Ferrer G et al (2007) The role of local knowledge in determining shade composition of multistrata coffee systems in Chiapas,
Mexico. Biodivers Conserv 16:419-436. doi:10.1007/ s10531-005-5436-3

Stewart DW, Shamdasani PN, Rook DW (2006) Focus groups: theory and practice. Sage, Thousand Oaks

Swinton SM, Lupi F, Robertson GP et al (2007) Ecosystem services and agriculture: cultivating agricultural ecosystems for diverse benefits. Ecol Econ 64(2):245-252. doi: 10.1016/j.ecolecon.2007.09.020

Teklay $\mathrm{T}$ (2007) Decomposition and nutrient release from pruning residues of two indigenous agroforestry species during the wet and dry seasons. Nutr Cycl Agroecosyst 77:115-126. doi:10.1007/s10705-006-9048-4

Tilman D, Wedin D, Knops J (1996) Productivity and sustainability influenced by biodiversity in grassland ecosystems. Nature 379:718-720. doi:10.1038/379718a0

Trujillo L (2008) Coffee production strategies in a changing rural landscape: a case study in Central Veracruz, Mexico. In: Bacon CM, Méndez VE, Gliessman SR et al (eds) Confronting the coffee crisis: fair trade, sustainable livelihoods and ecosystems in Mexico and Central America. MIT Press, Cambridge, pp 69-98

Verchot LV, Hutabarat L, Hairiah K et al (2006) Nitrogen availability and soil N20 emissions following conversion of forests to coffee in southern Sumatra. Global Biogeochem Cycles 20:GB4008. doi:10.1029/2005GB002469

Watanabe A, Takada H, Sarno et al (2007) Assessment of degradation and generation of humus in a coffee soil affected by weed cover by means of a stable carbon isotopic ratio. Eur J Soil Sci 58:1042-1049. doi:10.1111/ j.1365-2389.2006.00883.x

Westphal SM (2008) Coffee agroforestry in the aftermath of modernization: diversified production and livelihood strategies in post-reform Nicaragua. In: Bacon CM, Méndez VE, Gliessman SR et al (eds) Confronting the coffee crisis: fair trade, sustainable livelihoods and ecosystems in Mexico and Central America. MIT Press, Cambridge, pp 179-206

Williams BK (1983) Some observations on the use of discriminant analysis in ecology. Ecology 64:1283-1291. doi:10.2307/1937836

Wollni M, Zeller M (2007) Do farmers benefit from participating in specialty markets and cooperatives? The case of coffee marketing in Costa Rica. Agric Econ 37:243-248

Wong MTF, Gibbs P, Nortcliff S et al (2000) Measurement of the acid neutralizing capacity of agroforestry tree prunings added to tropical soils. J Agric Sci 134:269-276. doi:10.1017/S0021859699007388 